\title{
First Record of Scyllarine Lobster Chelarctus cultrifer (Crustacea: Decapoda: Scyllaridae) from Korea
}

\author{
Seok Hyun Lee and Hyun Sook Ko* \\ Department of Biological Sciences, Silla University, Busan 617-736, Korea
}

\begin{abstract}
The scyllarine lobster Chelarctus cultrifer is described as the first species of the genus Chelarctus known from Korean waters. C. cultrifer is very similar to the Galearctus kitanoviriosus but it is different in the pleura of the abdominal somites 2 to 4 are broader and ending in sharp posteriorly directed points and having the propodi of pereiopods 3 and 4 are forming subchelates with the dactyli. The record of the species represents an extension of its previously known range from Somalia to Hawaiian Islands and brings the number of known species of the scyllarine lobsters in Korea to three.
\end{abstract}

Keywords: Decapoda, scyllarine lobster, Chelarctus cultrifer, Korea

\section{INTRODUCTION}

The Indo-Pacific scyllarine lobsters consist of 14 genera (Acantharctus, Antarctus, Antipodarctus, Bathyarctus, Biarctus, Chelarctus, Crenarctus, Eduarctus, Galearctus, Gibbularctus, Petrarctus, Remiarctus, Scammarctus, and Scyllarides) and over 36 species are known (Holthuis, 2002). The genus Chelarctus Holthuis, 2002, was established for the species of Arctus cultrifer Ortmann, 1897, and could be characterized by a propodus of the pereiopod 3 with a distinct tooth in the distal part of the lower margin and forming a subchela with dactylus. In Korean waters, only two species in two genera [Scyllarides haanii (De Haan, 1841), Galearctus kitanoviriosus (Harada, 1962) (as Scyllarus kitanoviriosus)] have been reported (Kim and Kim, 1997).

Scyllarine lobsters caught in about $20 \mathrm{~m}$ depth by trap in Busan were identified as $C$. cultrifer. They are briefly described because of the first record of the species in Korea. The abbreviations used in the study are TL (total length from the tip of the rostrum to the extremity of the telson) and CL (carapace length from the tip of the rostrum to posterior margin of the carapace). The classification and terminology follow those of Holthius $(1991,2002)$. All specimens were preserved in $95 \%$ ethanol and deposited in the second author's collection of Silla University, Busan.

\footnotetext{
*To whom correspondence should be addressed

Tel: 82-51-999-5473, Fax: 82-51-999-5176

E-mail: hsko@silla.ac.kr
}

\section{SYSTEMATIC ACCOUNTS}

Superfamily Palinuroidea Latreille, 1802

Family Scyllaridae Latreille, 1825

${ }^{1 *}$ Genus Chelarctus Holthuis, 2002

2* Chelarctus cultrifer (Ortmann, 1897) (Fig. 1)

Arctus cultrifer Ortmann, 1897, p. 272.

Scyllarus cultrifer: Okada et al., 1974, p. 627; Takeda, 1982,

p. 43; Miyake, 1983, p. 85, pl. 29; Holthuis, 1991, p. 216

[name only]; Chan and Yu, 1993, pp. 217-219; Nishimura,

1995, p. 345, pl. 92; Minemizu, 2000, p. 123.

Chelarctus cultrifer: Holthuis, 2002, pp. 572-578, figs. 26, 27.

Materials examined. 1 б శ (TL $7 \mathrm{~cm}, \mathrm{CL} 2.8 \mathrm{~cm}$ ), 1 ovi. 우 (TL $11 \mathrm{~cm}$, CL $3.5 \mathrm{~cm}$ ), 27 Mar. 2008, by trap in $20 \mathrm{~m}$ depth, 1 가 (TL $8.2 \mathrm{~cm}$, CL $2.9 \mathrm{~cm}$ ), 1 ovi. 우 (TL $9 \mathrm{~cm}$, CL $3 \mathrm{~cm}$ ), 25 Jun. 2009, by trap in $20 \mathrm{~m}$ depth, Gilcheon (Busan).

Description. Carapace (Fig. 1A-C) subrectangular. Rostrum broad and frontal margin narrowed by fissure. Rostral and gastric teeth well developed, no pregastric tooth on postrostral carina. Several flattened tubercles placed between postrostral carina and cervical groove. Cervical groove divided branchial carina into anterior branchial carina and posterior branchial carina; 2 sharp teeth of equal size on anterior branchial carina, sharp pointed tooth and 2 rows of 8-12 distinct tubercles on posterior branchial carina. 3 sharp teeth on lateral margin of carapace. Postorbital tubercle present.

Abdomen (Fig. 1D) with arborescent pattern of deep transverse grooves on dorsal surface. Abdominal somites 2-4 with

$1 *$ 예 쁜매미새우속 (신칭), ${ }^{2 *}$ 예쁜매미새 우 (신칭) 


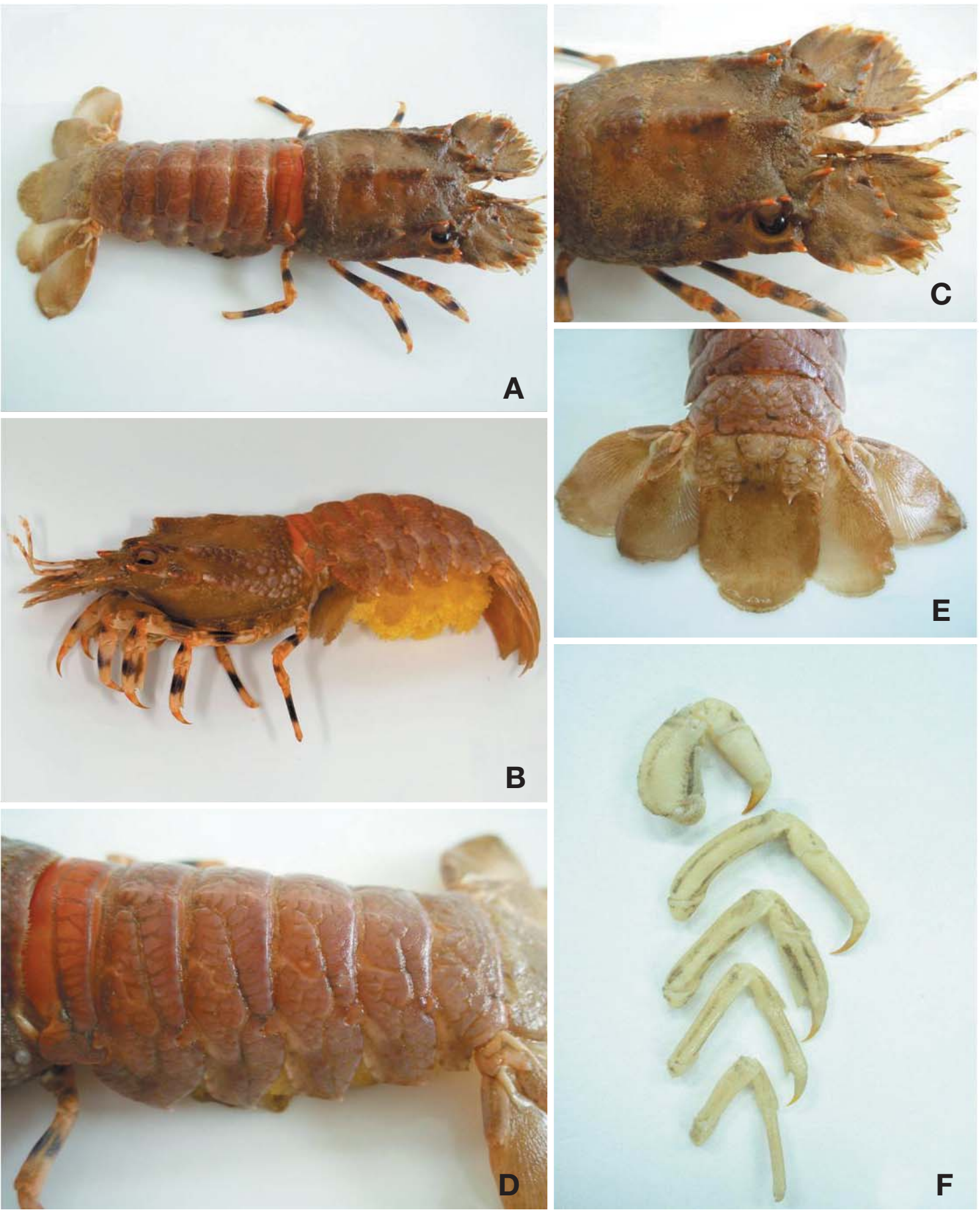

Fig. 1. Chelarctus cultrifer (A, C-F: male, $T L 8.2 \mathrm{~cm}, C L 2.9 \mathrm{~cm}$; B: female, $T L 9 \mathrm{~cm}, C L 3 \mathrm{~cm}$ ). A, dorsal view; $B$, lateral view; C, carapace and antennular somites; $D$, lateral view of abdomen; $E$, telson and tail fan; $F$, right pereiopods.

longitudinal median carina on dorsal surface, triangular median incision distinct on posterior margin in somites 1-3, but indistinct in somite 4, and absent in abdominal somites 5, 6 . Pleuron of abdominal somite 1 bilobed, pleura of somites 2-
4 broad and ending in sharp posteriorly directed point, pleuron of somite 5 having blunt angle.

Telson (Fig. 1E) rectangular, with arborescent pattern; 4 sharp teeth on posterior margin. 
Antennular somites (Fig. 1C) sinuous; inner margin of each half convex, outer margin of each half concave. Antennal segment 6 (Fig. 1C) convex, bearing 5 acute triangular teeth on distal margin and single tooth on inner margin; segment 5 with sharp tooth on internal angle; segment 4 with medial carina on dorsal surface, 2 large sharp pointed teeth on anterior margin, 2 acute triangular teeth on outer margin.

Pereiopods (Fig. 1F) generally short, compressed. Pereiopod 1 robust and shorter than the others, pereiopod 2 the longest, pereiopod 5 the slenderest. Merus with deep grooves on inner and outer margins of pereiopods. Carpus with deep groove on outer margin of pereiopods 3-5. Propodus with 2 deep grooves on medial surface of pereiopods 3-5, others naked. Dactylus hooked, having sharp pointed end, forming subchelate with propodus of pereiopods 3, 4 .

Color in life. Carapace dark brown, abdomen reddish brown. Pereiopod with yellowish white and purple bands over middle of merus, carpus, and propodus. Dactylus reddish yellow. Tail pan semi-transparent, grayish white.

Habitat. Hard bottom, coarse coral sand, muddy sand and mud (Holthuis, 2002).

Remarks. Korean specimens are almost identical to those of Chan and Yu (1993) and Holthuis (2002). However, some difference is in the lateral margin of carapace. 3 sharp teeth on lateral margin of carapace in the present specimens, while in Holthuis (2002) 5-6 teeth on lateral margin of carapace. C. cultrifer shows similarity more to G. kitanoviriosus than to $S$. haani in Korean water, but differs in the following characteristics: 1) the pleura of the abdominal somites 2 to 4 are broader and ending in sharp posteriorly directed points; 2) the propodi of pereiopods 3 and 4 are forming subchelates with the dactyli.

Distribution. Somalia, Kenya, Seychelles, Madagascar, Indonesia, Japan, Hawaiian Islands (Holthuis, 2002) and now Korea.

\section{ACKNOWLEDGEMENTS}

The authors thank to Captain of Daeseongho for collecting materials. This research was supported by the project on survey and excavation of Korean indigenous species of the National Institute of Biological Resources (NIBR) under the Ministry of Environment, Korea.

\section{REFERENCES}

Chan, T.Y. and H.P. Yu, 1993. The illustrated lobsters of Taiwan. SMC Publishing Inc., Taipei, pp. 1-247.

Holthuis, L.B., 1991. FAO species catalogue. Vol. 13. Marine lobsters of the world. An annotated and illustrated catalogue of species of interest to fisheries known to date. FAO fisheries synopsis No. 125, Vol. 13. FAO, Rome, pp. 1-292.

Holthuis, L.B., 2002. The Indo-Pacific scyllarine lobsters (Crustacea, Decapoda, Scyllaridae). Zoosystema, 24(3): 499-683.

Kim, H.S. and W. Kim, 1997. Decapoda In: List of animals in Korea (excluding Insects). Academy Publishing Co., Seoul, pp. 212-223.

Minemizu, R., 2000. Marine Decapod and Stomatopod Crustaceans mainly from Japan. Buninchi Sogo Publishing Co., Ltd., Tokyo, pp. 1-344. (in Japanese)

Miyake, S., 1983. Japanese Crustacean Decapods and Stomatopods in color Vol. I Macrura, Anomura and Stomatopoda. Hoikusha Publishing Co. Ltd., pp. 1-261, pls. 1-56. (in Japanese)

Nishimura, S., 1995. Guide to seashore animals of Japan with color pictures and keys Vol. II. Hoikusha Publishing Co., Ltd., pp. 1-663. (in Japanese)

Okada, K., S. Uchida and T. Uchida, 1974. New illustrated encyclopedia of the fauna of Japan. Vol. II. Hokuryukan Co., Ltd., pp. 1-803. (in Japanese)

Ortmann, A.E., 1897. Carcinologische Studien. Zool. Ja. Syst., 10: 258-372, pl. 17.

Takeda, M., 1982. Keys to the Japanese and foreign Crustaceans. Hokuryukan Ltd., Tokyo, pp. 1-284. (in Japanese)

Received October 4, 2010 Accepted November 12, 2010 